\title{
PAMERAN, PERSONAL SELLING DAN IKLAN MEDIA ONLINE DALAM MENDORONG PENJUALAN PROPERTY
}

\author{
Oleh: \\ M. Echsanullah'1); Anna Wulandari'2) \\ PT. Taman Firdaus'); Sekolah Tinggi Ilmu Ekonomi Pelita Bangsa2) \\ tamanfirdaus.kaffah@gmail.com ${ }^{1)}$; drannawulandariauthor@gmail.com ${ }^{2)}$
}

\begin{abstract}
ABSTRAK
Penelitian bertujuan untuk menganalisis pengaruh pameran, personal selling dan iklan media online terhadap penjulan property pada PT. Taman Firdaus

Penelitian dilakukan di PT. Taman Firdaus dengan mengambil data dari tabel biaya penjualan dan promosi sebagai sampel penelitian. Pengambilan data dilakukan dengan observasi dan dokumentasi. Analisis data menggunakan analisis regresi linier ganda.

Penelitian ini menghasilkan model penelitian yang layak karena pameran, personal selling dan iklan media online mampu menjelaskan 53,9\% variasi penjulan property pada PT. Taman Firdaus, dimana: 1) Pameran memiliki pengaruh dengan arah positip sebesar b1 $=176,401$ terhadap penjulaan property; 2) Personal Selling memiliki pengaruh pengaruh dengan arah positip sebesar $b 2=152,570$ terhadap penjulaan property; 3) Iklan Media Online memiliki pengaruh dengan arah positip sebesar b3 $=194,449$ terhadap penjulaan property pada PT. Taman Firdaus
\end{abstract}

Kata kunci:

Pameran, Iklan Media Online, Personal Selling, Penjualan

\section{PENDAHULUAN}

Bisnis property adalah menyangkut kebutuhan primer masyarakat, yang terdiri dari unsur sandang pangan dan papan. Urbanisasi yang cepat, cluster living, meningkatnya jumlah masyarakat kelas menengah dan bangkitnya industri baru akan membentuk industri properti dalam beberapa dekade ke depan dan berkontribusi pada percepatan yang luar biasa.

Bisnis sektor properti dan real estate tentu saja akan menarik baik dari sisi investasi (investor) maupun dari konsumen akhir (end user), dikarenakan faktor property yang selalu naik harganya dan sekaligus disisi lain bahan baku industry property adalah tanah yang semakin mahal karena faktor supplynya yang tetap, sementara demandnya terus naik berbanding lurus dengan pertumbuhan penduduk.

Sektor industry properti memiliki andil yang cukup besar terkait peningkatan perekonomian negara dengan multiplier effect. Industri bisnis property menurunakan 174 industri turunannya yang masih berkaitan dengan sektor properti. Mulai dari industri keramik, baja, paku, baja ringan, semen, jasa konstruksi, 
jasa perencanaan, cat, alat listrik, elektronik, hingga mebel, dll. Sektor perumahan memberikan kontribusi terhadap sekitar 9,61\% tenaga kerja di berbagai sektor yang bersinggungan dengan properti. Hal ini juga menunjukkan bahwa perkembangan sektor properti berpengaruh cukup besar terhadap sektor lainnya. Oleh karenanya, perlu ada peran lebih dari sektor properti dalam usaha meningkatkan pertumbuhan ekonomi nasional.

Bisnis property adalah bisnis yang padat modal. Kemampuan perusahaan dalam mengelola percepatan penjualan menjadi penting untuk mengembalikan perputaran dana dalam jangka waktu yang terukur. Adapun kebutuhan alokasi modal dibutuhkan untuk masing komponen sebagai berikut: Biaya Pembebasan Lahan; Biaya Legalitas (sertifikasi induk \& pemecahan sertifikat); Biaya Perizinan Proyek (Siteplan); Biaya Pembangunan infrastruktur (sarana jalan \& prasarana); Biaya Pembangunan fasilitas sosial dan umum (Taman, Sarana Ibadah Masjid, dll ); Biaya Pembangunan unit-unit property nya; Biaya Operasional Proyek; Biaya Marketing; Biaya lain - lain.

Untuk mengcover biaya yang timbul, maka dibutuhkan pendapatan yang bersumber dari penjualan. Untuk mencapai penjualan perlu strategi marketing yang tepat. Maka menjadi penting perusahaan memfokuskan pada usaha pemasaran agar perusahaan dapat menjaga kelangsungan survival bisnisnya.

Perlambatan bisnis property diprediksi masih terus berlanjut hingga tahun 2020. Mulai kelihatan kondisi kelesuan bisnis property ketika memasuki tahun 2014. Daya beli masyarakat yang belum pulih dan menunjukan kecenderuangan semakin menurun ditenggarai sebagai biang keladi lambatnya investasi di sektor property.
Kendati tingkat penjualan pada beberapa proyek properti tertentu terlihat menggeliat, namun hal itu belum cukup kuat membangkitkan gairah pasar properti. Hal ini terungkap dalam laporan Bank Indonesia (BI) mengenai Survei Harga Properti Residensial yang dirilis 13 November 2017. Laporan tersebut menyebutkan, responden yang disurvei memperkirakan perlambatan bisnis properti bakal berlanjut sampai akhir tahun ini. Untuk diketahui, responden yang disurvei merupakan pengembang yang beroperasi di wilayah Jakarta, Bogor, Depok, Bekasi, dan Banten serta 15 kantor perwakilan dalam negeri Bank Indonesia. Sebagian besar responden berpendapat, faktor utama yang menghambat pertumbuhan bisnis properti adalah tingginya suku bunga KPR. Responden yang menjawab ini sebanyak 20,36 persen. Sementara penyebab berikutnya adalah uang muka rumah (16,57 persen), pajak (16,13 persen), lamanya perizinan 14,45 persen, serta kenaikan harga bahan bangunan sebanyak 11,86 persen. Selain itu penyebab yang tidak kalah pentingnya dan menjadi faktor utama yang patut diantisipasi dari perlambatan penjualan bisnis property bukan hanya sebatas faktor makro enonomi seperti eskalasi harga bahan bangunan, biaya perizinan, tapi lebih merupakan sentimen pasar investasi menghadapi tahun pilkada.

Dalam sebuah perusahaan pada umumnya dan lebih khusus dibisnis pengembang property, marketing memegang peran penting untuk melakukan komunikasi terpadu yang bertujuan memberi informasi dari pihak perusahaan kepada konsumen mengenai barang (rumah) yang ditawarkan. Kebutuhan akan rumah tinggal adalah kebutuhan primer dan banyak keputusan variable yang akan diambil dalam memutuskan pembelian rumah. Disinilah 
menjadi penting ada penghubung antara produsen perumahan disatu sisi dan konsumen perumahan disisi lainnya guna menjembatani informasi tersebut maka peranan marketing sebagai media informasi menjadi sangat penting. Media informasi ini menjadi penting guna mencapai tujuan untuk memenuhi kebutuhan dan keinginan konsumen atau pelanggan. Proses dalam pemenuhan kebutuhan dan keinginan ini, kemudian dikenal menjadi konsep marketing yang biasa dijabarkan dalam bentuk bauran promosi.

PT. Taman Firdaus, adalah perusahaan yang bergerak disektor pengembang perumahan. Yang telah memulai bisnis perumahan terhitung sejak tahun 1995 yang semula bermain diusaha pengkavlingan tanah selanjutnya secara bertahap terus berkembang sehingga mampu untuk menapaki menjadi pengembang perumahan (developer property). Sebagaimana kondisi global kelambatan bisnis property yang juga dirasakan di Indonsesia secara umum, namun memberikan dampak juga pada penurunan (fluktuasi) penjualan unit - unit property di PT. Taman Firdaus.

Untuk

mempertahankan kelangsungan bisnis property perusahaan PT. Taman Firdaus, dimana kata kuncinya terletak di marketing, yakni penjualan. Tanpa terjadinya penjualan maka akan sangat cepat bisnis ini mengalami stagnasi karena tidak adanya casflow yang berputar ditambah lagi ada beban kewajiban pengembalian utang bank berupa angsuran pokok dan beban bunganya. Dan tentu sangat bahaya bagi perusahaan yang proporsi pembiayaan proyeknya tidak hanya bergantung pada rasio modal sendiri tapi juga sebagian ditutupi dengan dana pinjaman dari perbankan, biasanya berupa Kredit Modal Kerja atau kredit konstruksi pembangunan proyek, apalagi khusus untuk sektor bisnis property di perumahan subsidi yang pembiayaanya yang diwajibkan dibundle yakni antar kredit konstruksi dan kredit kepemilikan lahan (KPL) dalam satu paket.

Tahun 2000 sampai dengan tahun 2005 konsep marketing yang diterapkan tidak menunjukan perkembangan yang memuaskan. Namun sejak tahun memasuki 2006, perusahaan mengambil langkah - langkah promosi yang beragam antara lain menggunakan: iklan media cetak seperti koran, majalah; marketing street seperti; billboard, papan reklame, spanduk, penyebaran flyer dan brosur ditempat - tempat keramaian seperti terminal bus, stasiun keretap api; pameran seperti open table diperusahaan perusahaan serta pameran di ajang lokai di mall lokal setempat hingga ke convention hall yang bersifat nasional; media online seperti menggunakan Google Adwords, Facebook Advertising, Youtube ; personal selling seperti flyer, penyebaran brosur, mendatangi areal $2 \mathrm{~s} / \mathrm{d} 5 \mathrm{Km}$ door to door untuk memprospek lingkungan dimana proyek berada / berlokasi.

Dari berbagai bentuk promosi tersebut ada kecenderungan / fenomena bahwa pameran, iklan media online \& personal selling mendapatkan perhatian lebih, sehingga ketiga bentuk promosi tersebut yang berpotensi paling besar dalam mempengaruhi penjualan. Oleh karena itu penelitian ini menggunakan variable Pameran, Media Online dan Personal Selling dalam mempengaruhi penjualan menjadi objek penelitian penulis, untuk mengetahui seberapa besar peranan variable masing-masing atas terjadinya kontribusi penjualan di PT. Taman Firdaus. Dugaan sementara ini ditambah lagi didukung oleh penelitian, walaupun objek penelitiannya berbeda namun secara prinsip keilmuan meletakan dasar - dasar yang sama tentang pentingnya ketiga 
variabel diatas berperan dalam memberikan dampak penjualan di perusahaan PT. Taman Firdaus.

Pentingnya pameran dalam mempengaruhi penjualan diungkap dalam penelitian yang dilakukan oleh Joko Mei Rianto dan Meizy Herriyanto (2015); Emi Supariyani (2004).

Pentingnya Personal Selling dalam mempengaruhi penjualan diungkap dalam penelitian yang dilakukan oleh Dian Yudhiartika dan Jony Oktavian Haryanto (2012). Pentingnya Iklan Media Online dalam mempengaruhi penjualan diungkap dalam penelitian yang dilakukan oleh Heru Nugroho dan Kastaman (2014); Herdian Rizky Yuniyanto (2017).

\section{TUJUAN PENELITIAN}

Tujuan umum penelitian ini adalah untuk mengetahui dan menganalisis pengaruh Pameran, Personal Selling dan Iklan Media Online terhadap Penjualan pada PT. Taman Firdaus.

\section{TELAAH LITERATUR DAN PENGEMBANGAN HIPOTESIS \\ Literatur \\ Promosi dan Bauran Promosi}

Promosi adalah berbagai kegiatan menonjolkan keistimewaan perusahaan dengan tujuan membujuk konsumen sasaran agar membeli yang ditawarkan (Kotler, 2005). Promosi dilakukan dengan berbagai macam cara yang disebut sebagai bauran promosi. Unsur bauran promosi (promotion mix) terdiri atas lima perangkat utama, yaitu: Advertising, Sales Promotion, Public Realation and Publisity (hubungan masyarakat), personal selling, dan direct marketing (Kotler, 2005: 264).

Pameran merupakan suatu usaha tersistematis untuk memperlihatkan / memeperagakan contoh model, contoh produk atau barang sesungguhnya, peta lokasi atau gambar disain atau suatu lokasi tertentu dalam suatu ukuran yang terukur dalam suatu urutan tertentu untuk menimbulkan atau rasa ingin tahu (antusias) lebih jauh kepada para pengunjung (Forsyth, 1987: 345). Macam pameran itu adalah: show, exhibition, expo, pekan raya, fair, bazaar, pasar murah.

Personal selling adalah presentasi pribadi oleh para wiraniaga (tenaga penjual) perusahaan dalam rangka mensukseskan penjualan dan membangun hubungan dengan pelanggan (Kotler dan Amstrong, 2001: 112). Pameran juga dapat diartikan sebagai bentuk komunikasi langsung face to face (tatap muka) antara wiraniaga (sales person) dan calon pelanggan untuk memperkenalkan suatu produk kepada calon pelanggan dan membentuk pemahaman pelanggan terhadap produk sehingga mereka kemudian akan mencoba membelinya.

Iklan adalah segala bentuk presentasi non-pribadi dan promosi gagasan, barang, atau jasa oleh sponsor tertentu yang harus dibayar (Kotler, 2009). Iklan Media Online atau social media marketing merupakan bentuk perpasaran internet yang berupaya mencapai tujuan pemasaran merek dan komunikasi melalui partisipasi diberbagai jaringan media social (Rognerud, 2008). Social media marketing terdiri dari upaya untuk menggunakan media social untuk membujuk konsumen yaitu melalui komputer yang terkoneksi/ terhubung ke jaringan Internet (Neti, 2011). Iklan Media Online sendiri adalah upaya pemasaran online dengan menampilkan sebuah situs web pada hasil pencarian search engine di Google dengan cara berbayar. Iklan online juga bias di gambarkan sebaga kegiatan memasang iklan untuk menawarkan produk atau jasa lewat dunia maya, yang tujuannya tidak lain adalah untuk meraih 
penjualan guna mencapai keuntungan dari kegiatan promosi via online marketing.

\section{Penjualan}

Penjualan adalah interaksi antara individu saling bertemu muka yang ditujukan untuk menciftakan, memperbaiki, menguasai atau mempertahankan hubungan pertukaran sehingga menguntungkan bagi pihak lain (Swastha, 2005 :403) . Penjualan dapat diartikan juga sebagai usaha yang dilakaukan manusia untuk menyampaikan barang bagi mereka yang memerlukan dengan imbalan uang menurut harga yang telah ditentukan atas persetujuan bersama.

Akititas penjualan adalah suatu kegiatan yang ditujukan untuk mencari pembeli, mempengaruhi dan memberikan petunjuk agar pembeli dapat menyesuaikan kebutuhannya dengan produk yang ditawarkan serta mengadakan perjanjian mengenai harga yang menguntungkan bagi kedua belah pihak (Moekijat, 2000: 488). Penjualan sangat dipengaruhi oleh bauran pemasaran yaitu Harga, Promosi, Kualitas, dan Saluran Distribusi

\section{Kerangka Pemikiran}

Jatuh bangunnya volume penjualan PT. Taman Firdaus tergantung efektivitas program promosi dilaksanakan. Penjualan sangat identik seberapa besar aktifitas pemasaran yang terkait dengan bauran promosi yang memegang peranan kunci. Berdasarkan promotion plan PT. Taman Firdaus aktifitas pemasaran dilaksanakan melalui (1) media cetak seperti pemasangan iklan di koran, majalah, newslatter, media lingkungan warga (2) Pameran, baik pameran yang berskala lokal di mall setempat dan skala nasional seperti di gedung pameran layaknya Convention Hall (3) Iklan Media Online seperti menggunakan website perusahaan difungsikan sebagai media pemasaran dikaitkan dengan jaringan iklan berbasis web seperti Google Ads, Facebook Ads, Olx , dll (4) Personal Selling seperti melakukan prospecting calon konsumen di areal $2 \mathrm{Km}$ sekitra proyek property berada dengan cara menyebar flyer, brosur, door to door dan open table dibeberapa tempat perbelanjaan dan mini market sekitar proyek.

Promosi sangat berperan penting terhadap penjualan unit-unit property. Promosi meliputi sejumlah kegiatan dapat dilakukan dengan tujuan untuk mendongkrak penjualan (Payne, 2000: 203). Promosi adalah berbagai kegiatan yang dilakukan oleh perusahaan yang menonjolkan keistimewaan-keistimewaan produknya yang membujuk konsumen sasaran agar membelinya (Kotler, 2002: 41). Promosi juga diartikan sebagai upaya membujuk orang untuk menerima produk, konsep dan gagasan (Boyd, 2000: 65).

\section{Pengaruh Pameran Terhadap Penjualan}

Pameran merupakan salah satu bentuk promosi yang dapat menentukan tingkat penjualan perusahaan (Patrick Forsyth 1987: 345). Pameran merupakan suatu usaha tersistematis untuk memperlihatkan / memeperagakan contoh model. Pameran memberikan pengaruh yang signifikan pada penjualan sepeda motor pada PT. Greetech Cakrawala Motorindo (Joko Mei Rianto \& Meizy Heriyanto, 2015 ). Kegiatan promosi melalui pameran ini dapat mempengaruhi peningkatan volume penjualan pada PT. Astra InternationalTbk (Emmy, 2004).

Dengan semakin berkembangnya ilmu pengetahuan dan teknologi yang sangat pesat dan modern, akan memberikan dampak yang positif bagi perusahaan yang bergerak dibidang industri, penjualan maupun jasa. Dengan keadaan seperti ini, 
tentu saja tidak menutup kemungkinan perusahaan-perusahaan akan bersaing ketat dengan perusahaan yang mengeluarkan produk yang sejenis. Perusahaan makin menyadari bahwa dengan adanya persaingan tersebut sangat sulit bagi perusahaan untuk membangun reputasi perusahaan, demikian pula sebaliknya sangat mudah untuk kehilangan reputasi perusahaan tersebut. Agar perusahaan tetap mampu bersaing dengan perusahaan lain yang mengeluarkan produk sejenis, maka manajemen perusahaan harus mampu mengolah perusahaannya dengan baik. Supaya konsumen atau pelanggan yang ada tidak beralih kepada perusahaan lain dengan produk yang sama. Perusahaan dituntut untuk lebih memahami segala kebutuhan dan keinginan konsumen atau perusahaan harus mampu menciptakan produk yang sesuai dengan kebutuhan konsumen. Hal yang sama juga berpotensi besar terjadi di PT. Taman Firdaus sehingga dapat diduga bahwa pameran berpengaruh terhadap penjualan di PT. Taman Firdaus.

H1: Pameran berpengaruh terhadap penjualan di PT. Taman Firdaus.

\section{Pengaruh Personal Selling terhadap Penjualan}

Menurut pendapatan Kotler dan Amstrong (2001:112) mengatakan bahwa personal selling adalah presentasi pribadi oleh para wiraniaga (tenaga penjual) perusahaan dalam rangka mensukseskan penjualan dan membangun hubungan dengan pelanggan. Sedangkan menurut Mc Daniel (2001:167), personal selling merupakan komunikasi langsung antara seorang perwakilan penjual dengan satu atau lebih calon pembeli dalam upaya untuk mempengaruhi satu dengan lainnya dalam situasi pembelian. Hal ini diperkuat oleh penelitian ( 2012 ) yang dilakukan oleh
Dian Yudhiartika \& Jony Oktavian Haryanto yang menunjukan bahwa personal selling memiliki efek positif terhadap keinginan untuk membeli produk. Diperkuat lagi oleh hasil penelitian yang dilakukan oleh Desak Ketut Yunita Kusmayani. Anjuman Zukhri,Luh Indrayani, ( 2014 ), penelitian menunjukkan bahwa personal selling mempunyai pengaruh terhadap keputusan pembelian juga berpotensi besar terjadi di PT. Taman Firdaus.

H2: Personal selling berpengaruh terhadap penjualan di PT. Taman Firdaus.

\section{Pengaruh Iklan Media Online Terhadap Penjualan}

Mengutip pendapat Rognerud (2008) menyatakan bahwa Social media marketing atau iklan media online merupakan bentuk perpasaran internet yang berupaya mencapai tujuan pemasaran merek dan komunikasi melalui partisipasi diberbagai jaringan media social. Menurut Neti (2011) Social media marketing terdiri dari upaya untuk menggunakan media social untuk membujuk konsumen yang satu perusahaan, Produk dan/atau jasa yang berarti, Social media marketing. Hal yang sama diperkuat oleh penelitian yang dilakukan oleh diteliti oleh Achmad Jamaludin, Zainul Arifin \& Kadarismasn Hidayat ( April 2015 ), yang menunjukan bahwa Promosi Online dan Persepsi Harga berpengaruh signifikan terhadap Keputusan Pembelian. Selanjutnya penelitian yang dilakukan oleh Winda Sari ( 2000 ), media periklanan melalui internet di Indonesia merupakan peluang sekaligus tantangan yang harus dihadapi dalam menjalankan kegiatan dan operasional mereka. Penelitian ini bertujuan untuk melihat dampak pelaksanaan program periklanan di internet. Hasil yang diperoleh dari penelitian ini menunjukkan 
bahwa keputusan pembelian bagi pengguna internet di pengaruhi dari variabel periklanan di internet. Hal yang sama juga berpotensi besar terjadi di PT. Taman Firdaus, ketika pemasaran melakukan media online ada kecenderungan penjualan meningkat, oleh kareana itu dapat diduga bahwa iklan media online berpengaruh terhadap penjualan di PT Taman Firdaus.

H3: Iklan media Online berpengaruh terhadap penjualan di PT. Taman Firdaus.

\section{Gambar 1}

Kerangka Pemikiran

\begin{tabular}{|c|c|}
\hline $\begin{array}{c}\text { Pameran } \\
\text { (PatrickForsyth, 1987:345) }\end{array}$ & \\
\hline $\begin{array}{c}\text { Personal Selling } \\
(\text { Kotler dan Amstrong, 2001: 12) }\end{array}$ & $\begin{array}{c}\text { Penjualan } \\
\text { (Swasta, 2005: 65) }\end{array}$ \\
\hline $\begin{array}{l}\text { IKlan Media Online } \\
\text { (Rognerud, 2008) }\end{array}$ & H3 \\
\hline Alur & Sumber \\
\hline Pameran $\rightarrow$ Penjualan & Rianto \& Herriyanto (2015); Supariyani (2004) \\
\hline Personal Selling $\rightarrow$ Penjualan & Yudhiartika dan Harryanto (2012); Wicaksono (2017 \\
\hline Iklan Media Online $\rightarrow$ Penjualan & Nugroho dan Kastaman (2014); Yuniyanto (2018) \\
\hline
\end{tabular}

\section{METODE PENELITIAN}

Tempat Penelitian

Penelitian ini diadakan pada PT. Taman Firdaus. Penelitian dilaksanakan selama 3 (tiga) bulan yaitu dari bulan Oktober sampai dengan Desember 2017.

\section{Operasionalisasi Variabel}

Variabel penelitian secara operasional adalah sebagai berikut:
Tabel 1

Operasionalisasi Variabel

\begin{tabular}{|c|c|}
\hline Variabel & Pengukuran \\
\hline $\begin{array}{l}\text { Pameran adalah suatu usaha tersistematis untuk } \\
\text { memperlihatkan / memeperagakan contoh model, } \\
\text { contoh produk atau barang sesungguhnya, peta lokasi } \\
\text { atau gambar disain atau suatu lokasi tertentu dalam } \\
\text { suatu ukuran yang terukur dalam suatu urutan tertentu } \\
\text { untuk menimbulkan atau rasa ingin tahu (antusias) } \\
\text { lebih jauh kepada para pengunjung (Forsyth, 1987:345) }\end{array}$ & $\begin{array}{l}\text { Biaya Pameran } \\
\text { Triwulanan tahun } \\
2007 \text { s.d } 2016\end{array}$ \\
\hline $\begin{array}{l}\text { Social media marketing atau iklan media online adalah } \\
\text { bentuk perpasaran internet yang berupaya mencapai } \\
\text { tujuan pemasaran merek dan komunikasi melalui } \\
\text { partisipasi diberbagai jaringan media social (Rognerud, } \\
\text { 2008). }\end{array}$ & $\begin{array}{l}\text { Biaya Iklan Media } \\
\text { Online Triwulanan } \\
\text { tahun } 2007 \text { s.d } 2016\end{array}$ \\
\hline $\begin{array}{l}\text { Personal selling adalah presentasi pribadi oleh para } \\
\text { wiraniaga (tenaga penjual) perusahaan dalam rangka } \\
\text { mensukseskan penjualan dan membangun hubungan } \\
\text { dengan pelanggan (Kotler dan Amstrong, 2001:112). }\end{array}$ & $\begin{array}{l}\text { Biava Personal } \\
\text { Selling Triwulanan } \\
\text { tahun } 2007 \text { s.d } 2016\end{array}$ \\
\hline $\begin{array}{l}\text { Volume penjualan adalah hasil penjualan seluruh } \\
\text { produk (produk lini) selama jangka waktu tertentu } \\
\text { (Swasta, 2005: 65) }\end{array}$ & $\begin{array}{l}\text { Penjualan } \\
\text { Triwulanan tahun } \\
2007 \text { s.d } 2016\end{array}$ \\
\hline
\end{tabular}

\section{Sampel Penelitian}

Sampel adalah bagian dari populasi yang dipilih untuk mewakili populasi tersebut (Mulyanto dan Wulandari, 2010: 100). Sampel pada penelitian ini adalah data promosi dan penjualan perusahaan triwulanan dari tahun 2007 sampai dengan 2016. Pengambilan sampel dilakukan dengan metode Purposive Sampling.

\section{Metode Pengumpulan Data}

Data penelitian diperoleh melalui observasi dan dokumentasi. Observasi dilakukan dengan pengamatan langsung sedangkan dokumentasi dilakukan dengan pengambilan data dari dokumen perusahaan.

\section{Metode Analisis}

Analisis data menggunakan analisis regresi linier ganda (Mulyanto dan Wulandari, 2010) yaitu meregresikan variable independen pameran $(\mathrm{X} 1)$, personal selling (X2) dan iklan media online $(\mathrm{X} 3)$ terhadap penjualan $(\mathrm{Y})$. Analisis regresi linier ganda meliputi:

- Uji Persyaratan Analisis dengan menggunakan uji asumsi klasik yang 
terdiri dari: uji normalitas, multikolinieritas, autokorelasi dan heteroskedastisitas.

- Uji Kelayakan Model menggunakan adjusted $R$ Square dan uji-F. Kemampuan variable independen dalam menjelaskan variable dependen ditunjukkan oleh nilai adjusted $\mathrm{R}$ Square dan model dinyatakan layak jika probabilitas penelitian lebih kecil dari taraf uji penelitian $(($ Sig. $F<\alpha)$.

- Uji Hipotesis menggunakan model persamaan regresi linier ganda $\mathrm{Y}=\mathrm{a}+$ b1X1 + b2X2 + b3X3 dan uji t. Arah pengaruh ditunjukkan oleh koefisien regresi bi dan ada pengaruh jika probabilitas penelitian lebih kecil dari taraf uji penelitian $(($ Sig. $t<\alpha)$.

\section{HASIL DAN PEMBAHASAN Hasil Penelitian}

Analisis regresi linier ganda dilakukan dengan tahapan dari uji persyaratan analisis, uji model dan uji hipotesis.

\section{Uji Persyaratan Analisis}

Uji persyaratan analisis regresi linier ganda menggunakan uji asumsi klasik.

1. Uji Normalitas terpenuhi karena pengujian normalitas secara grafik menghasilkan grafik Normal P-P Plot yang memperlihatkan titik-titik nilai residual pada grafik Normal P-P Plot menyebar di sekitar dan mengikuti arah garis diagonal.

2. Multikolinieritas terpenuhi karena masing-masing variabel independen memiliki nilai Tolerance lebih besar dari 0,2 (pameran $=0,987$; personal selling $=0,969 ;$ iklan media online $=$ 0,970) dan nilai VIF kurang dari 10 (pameran $=1,013$; personal selling $=$ 1,032; iklan media online $=1,031$ ).

3. Autokorelasi terpenuhikarena nilai Durbin-Watson hasil perhitungan sebesar $\mathrm{DW}=2.244$ termasuk dalam range $1.65<\mathrm{DW}(2.244)<2.35$ yang berarti tidak terjadi autokorelasi.

4. Heteroskedastisitas terpenuhi karena uji secara grafis mendapatkan titiktitik hasil perhitungan pada grafik scatter plot menyebar secara acak di atas dan dibawah titik origin, sebagian besar berada di range -2 s.d. 2 serta tidak membentuk pola tertentu.

\section{Uji Kelayakan Model}

Analisis regresi linier ganda menghasilkan table berikut:

Tabel 2

Model Summary Pengaruh Pameran, Iklan Media Online dan Personal Selling Terhadap Penjualan

Model Summary ${ }^{b}$

\begin{tabular}{|l|c|r|r|c|}
\hline Model & R & R Square & \multicolumn{1}{c|}{$\begin{array}{c}\text { Adjusted R } \\
\text { Square }\end{array}$} & $\begin{array}{c}\text { Std. Error of } \\
\text { the Estimate }\end{array}$ \\
\hline 1 & $.758^{\mathrm{a}}$ & .574 & .539 & 1348539244 \\
\hline
\end{tabular}

a. Predictors: (Constant), Med. OL (X3), Pameran (X1), Pers. Sel (X2)

b. Dependent Variable: Penjualan ( $Y)$

Sumber: Data penelitian yang diolah, 2017

Nilai Adjusted R Square sebesar 0.539 yang menunjukkan bahwa Pameran, Iklan Media Online dan Personal Selling dalam model secara bersama-sama mampu menjelaskan 53,9\% variasi Penjualan.

Tabel 3

Anova Pengaruh Pameran, Iklan Media Online dan Personal Selling Terhadap Pejualan

\begin{tabular}{|c|c|c|c|c|c|c|}
\hline \multicolumn{2}{|c|}{ Model } & $\begin{array}{l}\text { Sum of } \\
\text { Squares }\end{array}$ & df & Mean Square & $F$ & Sig. \\
\hline \multirow[t]{3}{*}{1} & Regression & $8.828 E+19$ & 3 & $2.943 E+19$ & 16.182 & $.000^{b}$ \\
\hline & Residual & $6.547 E+19$ & 36 & $1.819 E+18$ & & \\
\hline & Total & $1.538 \mathrm{E}+20$ & 39 & & & \\
\hline
\end{tabular}

Sumber: Data penelitian yang diolah, 2017 
Kelayakan model ditunjukkan oleh nilai Adjusted $\mathrm{R}$ Square 0.539 dan probabilitas F sebesar Sig. F=0,000. Karena probabilitas $\mathrm{F}$ hitung lebih kecil daripada taraf uji penelitian (Sig $\mathrm{F}<\alpha$ atau $0.000<$ 0.05), maka dan Adjusted R Square 0.539 telah lebih besar dari 0.5 maka model persamaan hasil penelitian memenuhi uji kelayakan model karena pada model tersebut Pameran, Personal Selling dan Iklan Media Online mampu menjelaskan $53,9 \%$ variasi penjualan.

\section{Uji Hipotesis}

Model persamaan regresi linier ganda diperoleh dari table berikut:

Tabel 4

Koefisien Pengaruh Pameran, Iklan Media Online dan Personal Selling Terhadap Pejualan

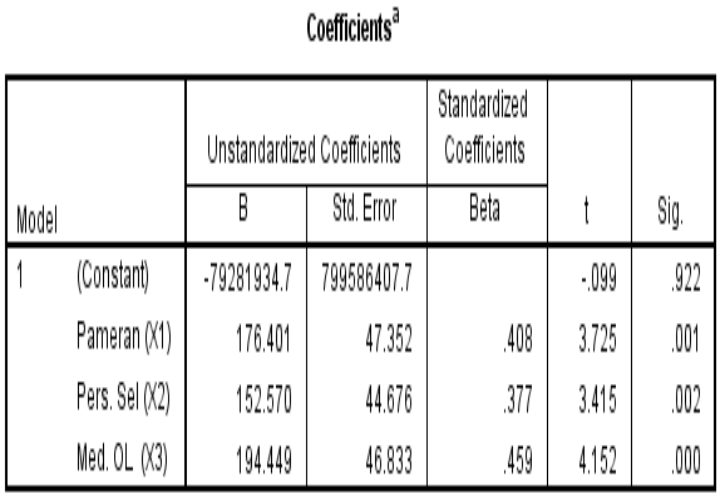

a. Dependent Variable: Peniulalan $(M)$

Sumber: Data penelitian yang diolah, 2017

Model persamaan regresi linier ganda hasil penelitian adalah:

$\hat{Y}=-79.281 .934,7+176,401 X 1+152,570 X 2+$ $194,449 \times 3$

Uji hipotesis berdasarkan table di atas:

1. Koefisien regresi Pameran (X1) sebesar b1 = 176,401 memiliki nilai probabilitas t hitung sebesar 0,001. Karena b1 \# 0 dan probabilitas $t$ hitung lebih kecil daripada taraf uji penelitian (Sig $\mathrm{t}<\alpha$ atau 0,001 < 0,05), maka pengaruh Pameran (X1) terhadap Penjualan (Y) adalah signifikan. Signifikansi hasil pengujian menunjukkan bahwa terdapat pengaruh Pameran terhadap Penjualan.

2. Koefisien regresi Personal Selling (X2) sebesar $b 2=152,570$ memiliki nilai probabilitas $\mathrm{t}$ hitung sebesar 0,001. Karena b2 \# 0 dan probabilitas t hitung lebih kecil daripada taraf uji penelitian (Sig $\mathrm{t}<\alpha$ atau 0,001 $<0,05$ ), maka pengaruh Personal Selling (X2) terhadap Penjualan (Y) adalah signifikan. Signifikansi hasil pengujian menunjukkan bahwa terdapat pengaruh Personal Selling terhadap Penjualan.

3. Koefisien regresi Iklan Media Online (X3) sebesar b3 = 194,449 memiliki nilai probabilitas $\mathrm{t}$ hitung sebesar 0,001. Karena b3 \# 0 dan probabilitas thitung lebih kecil daripada taraf uji penelitian (Sig $\mathrm{t}<\alpha$ atau 0,001 $<0,05$ ), maka pengaruh Iklan Media Online (X3) terhadap Penjualan (Y) adalah signifikan. Signifikansi hasil pengujian menunjukkan bahwa terdapat pengaruh Iklan Media Online terhadap Penjualan.

\section{Pembahasan}

Pengukuran variabel penelitian dilakukan dengan menggunakan kuesioner yang dikembangkan dari indikator pada masing-masing variabel penelitian. Dari hasil uji validitas terhadap masing-masing variabel penelitian ditemukan bahwa seluruh item pernyataan pada setiap variabel telah valid. Melalui uji reliabilitas ditemukan bahwa seluruh butir pernyataan yang telah valid pada masingmasing variabel penelitian dapat dibuktikan reliabilitasnya. Karena kuesioner telah valid dan reliabel maka kuesioner penelitian merupakan alat yang handal untuk mengukur masing-masing variabel penelitian. 
Penelitian menghasilkan model penelitian berupa persamaan regresi linier ganda ganda $\hat{Y}=-79281934.7+176,401 X 1+$ $152,570 X 2+194,449 X 3$. Berdasarkan uji model dengan uji-F diperoleh hasil yang signisikan sehingga hasil penelitian layak atau memenuhi goodness of fit test dimana pada model tersebut Pameran, Iklan Media Online dan Personal Selling mampu menjelaskan 53,9\% variasi Pejualan.

Gambar 2

Rangkuman Hasil Analisis

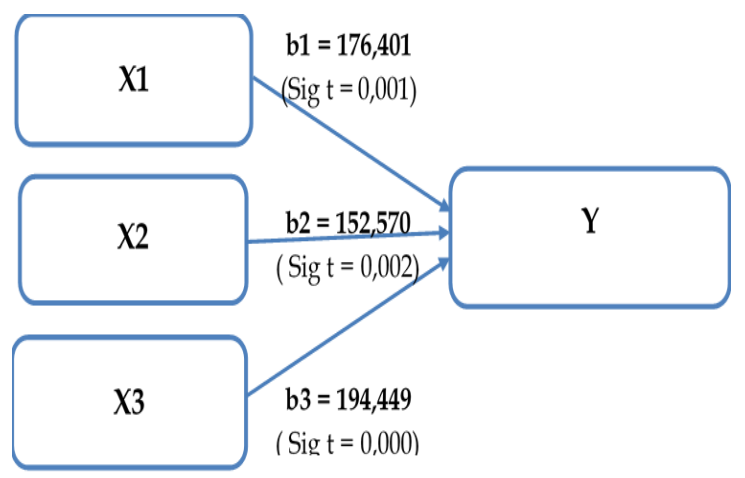

Adjusted R Square $=0,539$

$(\operatorname{Sig} \mathrm{F}=0,000)$

\section{Pengaruh Pameran terhadap Pejualan}

Pameran memiliki pengaruh terhadap Penjualan dengan arah positif sebesar b1 = 176,401, artinya makin tinggi biaya pameran maka makin tinggi pula penjualan yang berhasil diraih. Hasil penelitian sesuai dengan teori bahwa pemeran adalah salah satu ajang yang sering digunakan perusahaan dan pedagang untuk memperkenalkan produk yang mereka hasilkan sekaligus bagian untuk mempertinggi volue penjualan perusahaan (Patrick Forsyth, 1987). Penelitian ini juga sejalan dengan penelitian yang dilakukan oleh Emi Supariyani (2004) bahwa biaya promosi melalui pameran yang telah dikeluarkan perusahaan dapat meningkatkan volume penjualan pada PT. Astra InternationalTbk.
Konsekwensi dari hasil penelitian adalah perlunya meningkatkan kegiatan promosi melalui pameran. Perusahaan perlu menetapkan tujuan promosi yang akan membantu tercapainya tujuan perusahaan secara lebih luas (Kismono, 2001: 374). Penetapan promosi melalui pameran harus memperhatikan: a) Biaya yang harus dikeluarkan; b) Siapa Profile Pengunjung Pameran; c) Media yang tepat untuk mempercepat closing prospek prospek lama dan baru; d) Siapa pendukung pameran misalnya Lembaga Pembiayaan KPR seperti perbankan yang menawarkan pemberian diskon dari sisi bunga murah, hingga proses cepat untuk penilaian kelayakan KPR hingga hilangnya biaya provisi dll; e) Siapa yang akan hadir di pameran tersebut apa sesuai / tepat sasaran dari profile yang akan kita bidik; f) Seberapa Event Organizer memiliki kapabilitas dalam mengorganisasi suatu pameran.

\section{Pengaruh Personal Selling terhadap Penjualan}

Personal Selling memiliki pengaruh terhadap Penjualan dengan arah positif sebesar b2 $=152,570$, artinya makin tinggi biaya Personal Selling yang dikeluarkan maka makin tinggi pula Penjualan yang berhasil diraih. Personal selling adalah presentasi pribadi oleh para wiraniaga (tenaga penjual) perusahaan dalam rangka mensukseskan penjualan dan membangun hubungan dengan pelanggan (Kotler dan Amstrong, 2001: 112) sehingga mampu mendorong pembelian konsumen. Penelitian ini sejalan dengan apa yang dilakukan Dian Yudhiartika dan Jony Oktavian Haryanto (2012), dimana personal selling memiliki efek positif terhadap keinginan untuk membeli produk kecantikan Pond's.

Konsekwensi dari hasil penelitian adalah perlunya meningkatkan anggaran 
di personal selling, dengan cara: a) Manambah armada marketing / sales; b) Secara berkala mengadakan open house di lapangan; c) Bekerjasama dengan agen pemasaran untuk menambah database calon konsumen; d) Mengadakan kerjasama dengan koperasi perusahaan; e) Mengadakan open table di mal - mal dan kantor pemerintahan dan swasta.

\section{Pengaruh Iklan Media Online terhadap Penjualan}

Iklan Media Online memiliki pengaruh terhadap Penjualan dengan arah positif sebesar b3 $=194,449$, artinya makin tinggi biaya Iklan Media Online makin tinggi pula Penjualan yang dihasilkan. Penelitian ini ssesuai dengan apa yang dilakukan oleh Herdian Rizky Yuniyanto (2017) yang mengadakan penelitian mengenai media internet untuk melakukan pemasaran, salah satunya adalah Youtube. Hasil penelitian menunjukkan bahwa iklan berpengaruh positif signifikan terhadap brand recognition, brand recognition berpengaruh ositif signifikan terhadap minat beli, dan brand recognition tidak mampu berfungsi sebagai variabel intervening dalam hubungan antara iklan dan minat beli.

Konsekwensi dari hasil penelitian adalah perlunya meningkatkan anggaran iklan media online, dengan cara: a) Pembuatan Website yang lebih menarik; b) Memperbesar volume anggaran iklan di media online seperti youtube, Google Ads, Facebook , blog, Olx, Rumah.com, Property.com, rumah123.com; dan lainlain.

\section{KESIMPULAN}

Model hasil penelitian $\hat{Y}=-79281934.7$ $+176,401 X 1+152,570 X 2+194,449 X 3$ layak atau memiliki tingkat goodness of fit test karena pada model tersebut Pameran,
Iklan Media Online dan Personal Selling mampu menjelaskan 53,9\% variasi Pejualan.

1. Pameran memiliki pengaruh terhadap Penjualan pada PT. Taman Firdaus dengan arah positif sebesar b1 = 176,401, artinya semakin tinggi Pameran maka semakin tinggi pula Penjualan.

2. Personal selling memiliki pengaruh terhadap Penjualan pada Taman Firdaus dengan arah positif sebesar b2 $=152,570$, artinya semakin tinggi Personal Selling maka semakin tinggi pula Penjualan.

3. Iklan Media Online memiliki pengaruh terhadap Penjualan pada PT. Taman Firdaus dengan arah positif sebesar b3 $=194,449$, artinya semakin tinggi Iklan maka semakin tinggi pula Penjualan.

\section{SARAN}

1. Perusahaan hendaknya berupaya untuk menambah anggaran biaya untuk pameran, media online dan personal selling

2. Hasil Penelitian ini dapat digunakan sebagai bahan masukan organisasi bisnis yang lainnya atau lebih khusus pada bisnis di industry property sebagai satu landasan / rujukan untuk pengambilan kebiajakan / keputusan bisnis

3. Perlu penelitian lanjutan yang lebih mendalam dengan menggunakan variabel lainnya yang lebih lengkap atau dengan model objek penelitian yang berbeda yang kelak dapat menambah khasanah ilmu pengetahuan. 


\section{DAFTAR PUSTAKA}

Ferdinand, A., (2006) Metode Penelitian Manajemen. Semarang: Badan Penerbit Universitas Diponegoro.

Kastaman, H.N. (2014) Pengaruh Media Sosial Facebook Dalam Peningkatan Penjualan Bisnis Online

Kertajaya, H. (2000), "Integrating Sales Marketing, Jakarta: Mizan.

Kolter, P. (2005) Manajemen Pemasaran , Analisis Perencanaan Implementasi dan Control, edisi Bahasa Indonesia Penerbit PT. Prehallindo, Jakarta

Kotler, P. and Armstrong, G. (2012) Prisip - prinsip Pemasaran. Edisi 13, Jilid 1, Jakarta: Erlangga

Kotler, P. and Keller, K.L. (2012) Marketing Management $13 \mathrm{New}$ Jersey: Pearson Prentice Hall, Inc.

Mulyanto, H. dan Wulandari, A. 2010, Penelitian: Metode \& Analisis, Penerbit CV. Agung, Semarang Mursid (2008) Manajemen Pemasaran, Penerbit Bumi Aksara. Jakarta, BukU Pedoman akademik STIE Jayakarta 2015 - 2016, Penerbit STIE Jayakarta.

Rianto, J.M. dan Herriyanto, M. (2015) Publisitas Melalui Pameran Terhadap Tingkat Penjualan Sepeda Motor, Kasus Pada Sepeda Motor Kawasaki PT.
Greentech Cakrawala Motorindo Pekanbaru.

Supariyani, E (2004) Pengaruh Biaya Pelaksanaan Promosi Melalui Pameran Terhadap Tingkat Volume PENJUALAN pada PT. Astra International Tbk-IsuzU cabang Bogor

Swastha, B. (2009) Asaz-Asaz Marketing. Edisi ketiga. Cetakan ketujuh. Penerbit: Liberty. Yogyakarta.

Swastha, B. (2005) Pengantar Bisnis Modern. Jakarta : Salemba Empat.

Umar, H, (2008) Riset: SDM, Pemasaran, Keuangan, Strategi. Jakarta: PT. Gramedia Pustaka Utama.

Wicaksono, A.W. (2017), Analisis Pengaruh Kualitas Produk, Harga Dan Promosi Terhadap Keputusan Pembelian Handphone Merek Xiomi di Surakarta.

Yudhiartika, D dan Haryanto, J.O. (2012) Pengaruh Personal Selling, Display, Promosi Penjualan Terhadap Kesadaran dan Intensi Membeli Pada Produk Kecantikan Pond's.

Yuniyanto, H.R. (2017) Pengaruh Iklan terhadap Minat Beli Pengguna Youtube dengan Brand Recognition sebagai Variabel Intervening. 